\title{
Ecology of intertidal macroalgal assemblages on the Hadramout coast of southern Yemen, an area of seasonal upwelling
}

\author{
R. F. G. Ormond, S. A. Banaimoon* \\ Tropical Marine Research Unit, Biology Department, University of York, York YO1 5DD, United Kingdom
}

\begin{abstract}
The species composition and ecology of well-developed macroalgal assemblages that occur on racky shores of the Hadramout coast of southern Yemen were studied between January 1988 and February 1990. 163 taxa were collected. Qualitative data supported by quantitative biomass samples confirm that there is a very marked seasonal pattern in the growth of the algal species which also show a clear zonation from upper to lower intertidal. The majority of species show greatest growth during the late summer and autumn (August-September); a much smaller period of growth partly involving different species occurs in the spring (February-March), but during midsummer (May-June) no algal growth is apparent. The late summer/autumn period of maximum growth (with algal biomass typically 5 to 10 times that during spring) follows the onset of the southwest monsoon which is known to generate intense seasonal upwelling of cold nutrient-rich water along the southern Arabian coast, regarded as one of the 5 major upwelling areas within the world ocean system. Measurement of near-shore oceanographic parameters and analysis of local climatological data support the view that the dense autumn growth of intertidal algae occurs as a result of elevated nutrient levels consequent upon this upwelling. The smaller peak in growth in spring is also associated with some elevated nutrient levels, but further study is needed to determine whether this is linked to the onset of the northeast monsoon or to other seasonal factors.
\end{abstract}

KEY WORDS: Upwelling $\cdot$ Macroalgae $\cdot$ Rocky shore $\cdot$ Indian Ocean $\cdot$ Nutrients

\section{INTRODUCTION}

Macroalgae-dominated rocky shores are well known from many parts of the world, and have been especially well described in temperate regions (Lewis 1964 , Stephenson \& Stephenson 1972, Ray 1975). In tropical regions intertidal macroalgal communities are commonly much less well developed, and through much of the Arabian peninsula, for example, the narrow littoral zone is relatively devoid of macroalgae (Basson et al. 1977, Jones et al. 1987). Recently however it has been reported that on the rocky coasts of southern Arabia, in both the Dhofar region of southern Oman (Barratt et al. $1984,1986)$ and the eastern region of southern Yemen

\footnotetext{
-Present address: Department of Education, University of Aden, Mukalla, Yemen
}

(Banaimoon 1986, 1988a, b), dense growth of macroalgae occurs on a seasonal basis. Although these papers provide accounts of the occurrence and identification of some seaweed species found at sites in southern Yemen, and studies hitherto unpublished in the scientific literature (Barratt et al. 1984, 1986) have considered the composition and ecology of macroalgal communities in southern Oman, to date no account of the basic ecology of the intertidal macroalgae of southern Arabia or the Gulf of Aden has been published. The present paper describes the results of a study into the community structure, seasonal growth and association with environmental factors of the intertidal macroalgal assemblages found at a series of sites along the Hadramout coast of southern Yemen.

The most conspicuous aspect of the intertidal ecology of both Dhofar (Barratt et al. 1984, 1986) and Hadramout (Banaimoon 1986, in press) is that a dense 
stand of macroalgae develops during late summer and autumn, associated with the period of the southwest monsoon. Following the monsoon the algae die back, and for much of the year the intertidal zone is devoid of significant algal growth. The southwest monsoon, blowing almost parallel to the southern Arabian coast, is known to result in an area of intense upwelling in the adjacent Arabian Sea, regarded as one of the 5 major upwelling areas in the world ocean system (Currie 1964, 1992, Smith 1968, Bottero 1969, Currie et al. 1973, Bruce 1974, Smith \& Bottero 1977, Savidge et al. 1990). This upwelling, which reaches maximum development during July-August (Currie 1992), results in the displacement of warm oligotrophic water by colder nutrient-rich water. During this time seawater temperatures as low as $16^{\circ} \mathrm{C}$, nitrate concentrations as high as $20 \mu \mathrm{g}$-at. $\mathrm{NO}_{3}-\mathrm{N} \mathrm{I}^{-1}$ and phosphate concentrations as high as $5 \mu \mathrm{g}$-at. $\mathrm{PO}_{4}-\mathrm{Pl}^{-1}$ have been recorded in nearshore waters off the adjacent coast of southern Oman (Currie et al. 1973, Barratt et al. 1986, Savidge et al. 1990).

Seasonal growth of intertidal algae during the monsoon has also been described in parts of Sri Lanka (Svedelius 1906), India (Misra 1960), the Philippines (Kraft 1970) and Kenya (Moorjani 1979, 1982). Generally, seasonal periodicity in benthic algal growth in the tropics has been linked to increased light and temperature levels (Taylor \& Bernatowicz 1969, Croley \& Dawes 1970), to water movement (Gessner \& Hammer
1967. Santelices 1977) or to altered levels of herbivory (McClanahan 1988). In southern Arabia however it is presumed (Barratt et al. 1986) that the occurrence of dense macroalgal growth during the southwest monsoon is principally due to elevated seawater levels of inorganic nutrients, either nitrate and/or phosphate, although there is no direct evidence yet to demonstrate this. Similarly Fujita et al. (1989) have concluded from a study of the relationship between macroalgal growth and dissolved inorganic nutrient supply in an area of seasonal upwelling in Oregon, USA, that, prior to the commencement of upwelling in April and May, growth of Ulva rigida, a species also found in Yemen, was probably nitrogen limited. Therefore, during the present study, oceanographic and climatological data were also collected to provide further information about factors responsible for seasonality of macroalgal growth in southern Arabia.

\section{METHODS AND STUDY AREA}

The study was undertaken between January 1988 and February 1990 at 5 locations along the coast of the Hadramout which extends $720 \mathrm{~km}$ between $49^{\circ} 07^{\prime} \mathrm{E}$ and $50^{\circ} 21^{\prime} \mathrm{E}$, occupying the eastern part of the southern coast of Yemen (Fig. 1). This coast is irregular in form, but is dominated by a series of sandy bays of varying size separated by headlands, sometimes of a

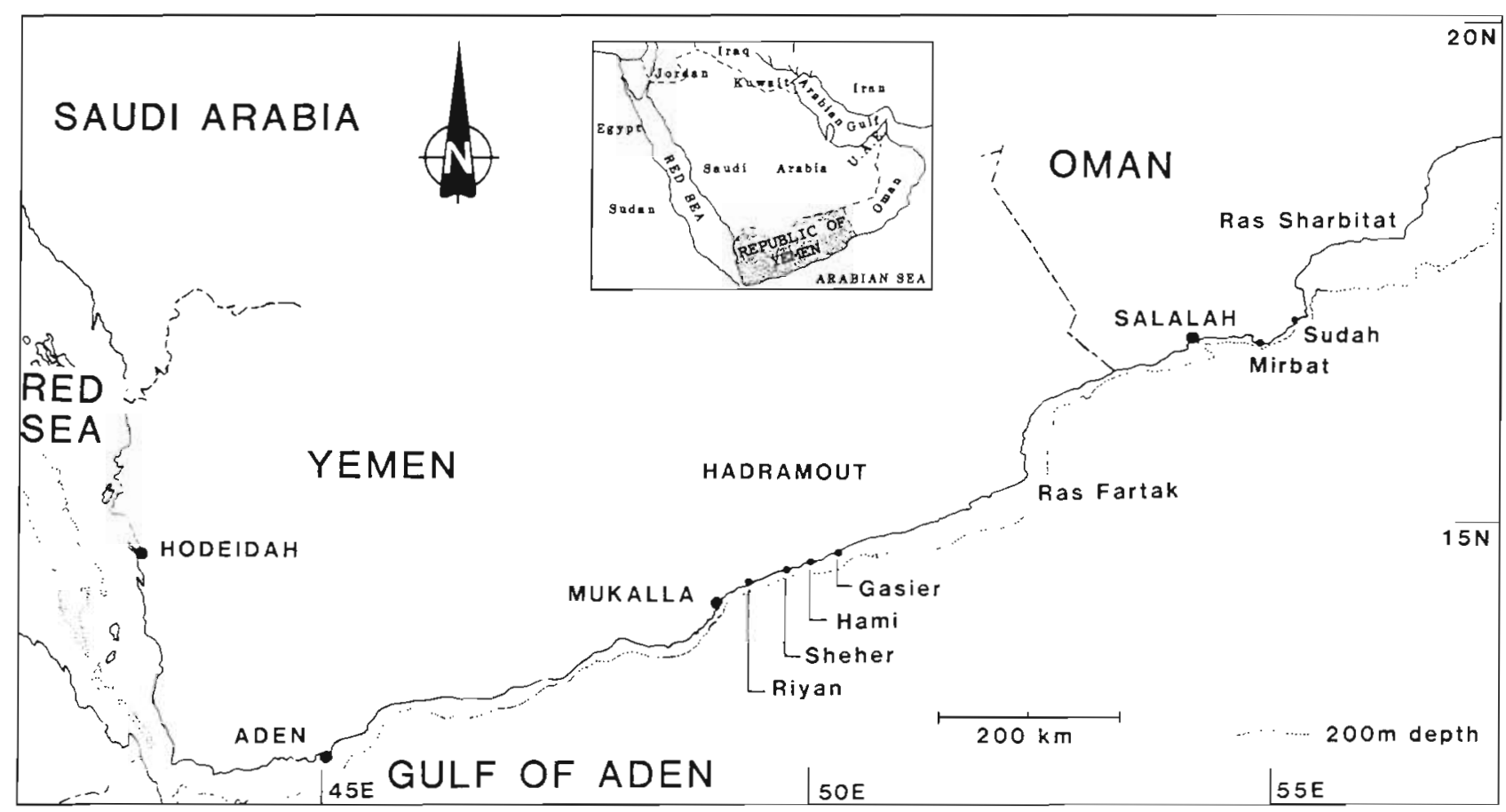

Fig. 1. Location of the 5 study sites on the Hadramout coast of southern Yemen in relation to the adjacent coast of southern Oman 
considerable height, of either igneous rock or of limestone.

Macroalgal and seawater samples were collected in 5 different areas: Mukalla (Khalf), Riyan (Al Dubbah), Sheher, Hami and Gasier (Fig. 1). Names of actual sampling stations are given in parentheses; in one area, Sheher, 2 different neighbouring stations were sampled, Motalla and Hofra. Of the sites, those at Al Dubbah, Sheher and Hami consist essentially of long broad sandy beaches giving way to rough but level limestone platforms in the lower intertidal and sublittoral zones. During the winter and spring these intertidal rocky platforms tend to be covered by shorewards-moving sand, but this sand is removed seawards again by the rougher wave action that occurs during the southwest monsoon. By contrast the sites at Khalf and Gasier are on shelving irregular rocky shores composed of hard igneous rock. Profiles of each type of shore (at Khalf and at Motalla) are shown in Fig. 2.

Qualitative macroalgal samples were collected from each of 3 zones - upper, middle and lower intertidal - defined by division of the shore between extreme high water and extreme low water into 3 equal-height vertical bands. Quantitative macroalgal samples were collected during July to September 1989 and January to March 1990 at 3 of the sites: Khalf (Mukalla), Motalla (Sheher) and Hofra (Sheher). These quantitative samples were taken by clearing all macroalgae from $1 \mathrm{~m}^{2}$ quadrats positioned randomly within each zone (upper, middle and lower intertidal). During each growth season (spring and autumn) 3 samples were collected from each of the 3 zones at each study site on each of 2 occasions. Samples were carefully bagged and returned to the laboratory for sorting, drying and weighing.

Seawater samples were collected in triplicate from near the shore, normally by boat. Samples were collected a minimum of 8 times over 1989 from each of the 3 main sampling stations. Temperature was recorded from a freshly collected seawater sample using a calibrated thermometer. Samples for chemical analysis were filtered through a Whatman GF/C filter and stored in acid-washed polypropylene or glass polystop bottles. Samples were kept on ice in a field cool-box pending return to the field laboratory where they were deep-frozen to $-20^{\circ} \mathrm{C}$. Subsequently they were transported to an analytical laboratory in Kuwait for analysis of total silicate (as an indicator of upwelling) and dissolved inorganic phosphate. Phosphate determination followed the method of Murphy \& Riley (1962) and silicate determination that described in Parsons et al. (1984). Analysis for nitrate, although desirable, was not available. Some samples were lost as a result of logistic problems associated with the region.

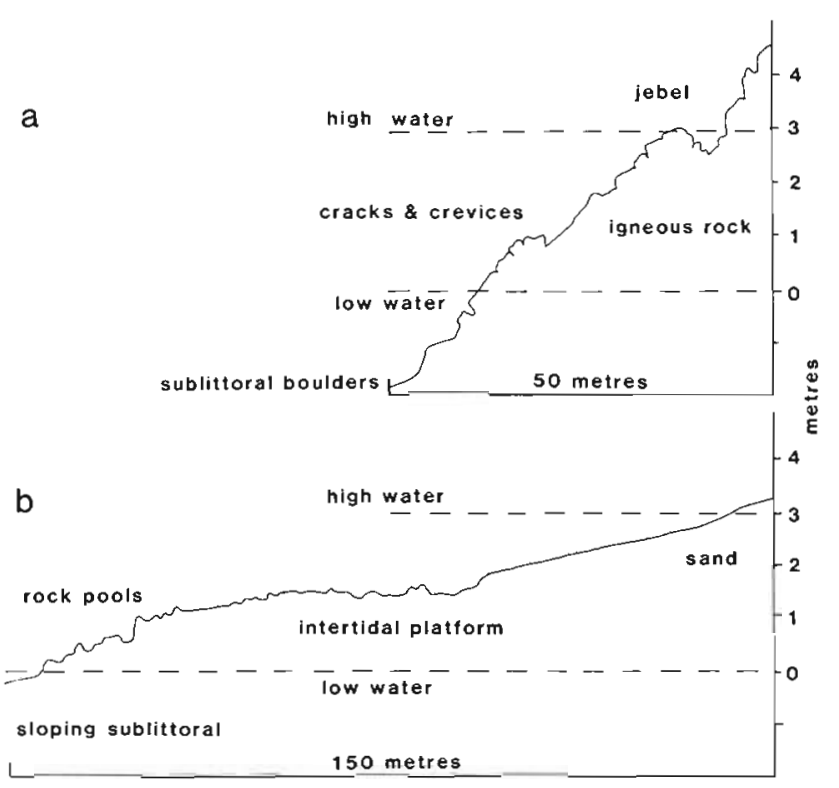

Fig. 2. Profiles of 2 of the study sites, (a) Khalf, Mukalla and (b) Motalla, Sheher, to show the contrasting form of igneous (as at Khalf) and limestone (as at Motalla) shores

Meteorological data were obtained from 1988 to 1990 with the assistance of the meteorological station at Riyan Airport.

\section{RESULTS}

\section{Algal species recorded}

As a result of general sample collection a total of 163 species of algae (46 Chlorophyta, 29 Phaeophyta and 88 Rhodophyta) were recorded in the rocky intertidal zone at study sites along the Hadramout coast. A full list of these species is given in the appendix which also indicates at which of the sites each species was recorded. A majority of species were recorded or abundant only during the period of the southwest monsoon (late summer and autumn). As described elsewhere (Banaimoon in press) most of these species represented new records for Yemen; 82 out of 163 are also new records for the Gulf of Aden, and 118 out of 163 are new records for Southern Arabia. In addition some appear to be previously undescribed species.

The number of species (species richness) of Chlorophyta, Phaeophyta and Rhodophyta recorded at each of the main sites is illustrated in Fig. 3. A similar pattern of variation in species richness with location along the Hadramout coast was apparent within each division; species richness increased passing east from Mukalla to Riyan to Sheher, and then declined slightly again on passing further east to Hami and then to Gasier. 


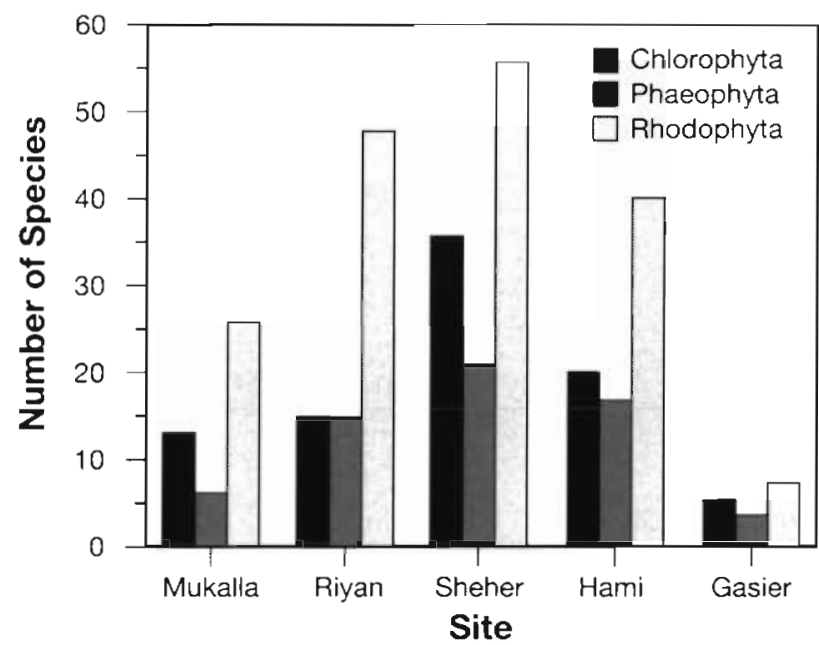

Fig. 3. Species richness (total number of species recorded) of Chlorophyta, Phaeophyta and Rhodophyta at each of the 5 study sites

\section{Zonation}

The common species (those observed at 3 or more locations within any study site) at different levels on the shore at each of the 3 main study sites, based on qualitative records, are shown in Table 1 . These data support evidence of a greater species diversity at Sheher than at Mukalla (Khalf), and also indicate increasing numbers of common species lower on the shore.

The upper shore at all sites was dominated by species of Ulva, Enteromorpha and Chaetomorpha, together with Dermonema frappieri and Porphyra vietnamensis at Khalf (Mukalla) and Padina spp. at the 2 Sheher sites (Motalla and Hofra). On the mid-shore at Khalf $D$. frappieri and $P$. vietnamensis were again abundant, as were Bryopsis pennata, Sarconema filiforme, Centrocerus clavulatum and Melanothamnus somalensis. In addition to these, at the Sheher sites Caulerpa cupressoides, Udotea indica, Laurencia papillosa, Dasya baillouviana and several species of Hypnea and Gracilaria were also common or abundant, as were the 3 Padina species found on the upper shore.

Further species found on the lower shore at Khalf included Caulerpa racemosa, Codium tomentosum, Spatoglossum asperum, Jolyna laminarioides, Meristotheca papullosa, Hypnea pannosa and 2 species each of Sargassum and Laurencia. Other species common on the lower shore at the 2 Sheher sites included Halimeda tuna, Stoechosperumum marginatum, Cystoseira trinodis, Sargassum binderi, Sargassum latifolium, Galaxuara marginata, Gelidiella acerossa, Grateloupia filicina, Champia parvula, Champia globulifera and Polysiphonia crassicolis

\section{Seasonal variation}

As indicated above, at all sites the extent and growth of algal cover varied markedly during the course of the year. During the winter (November, December) only minimal amounts of intertidal algae were present. During spring (January to March) there was modest growth of some algae, but this then died away altogether, and during early summer (May, June) no intertidal algae were found. However, following the onset of the southwest monsoon (June-July) there was rapid growth of a diverse algal assemblage that reached a peak in August and September. From October this in turn died back leaving the small amounts of algae found in winter. The growth present in autumn was several times greater than that which occurred in spring, the latter also extending not as far up the shore as the growth during the autumn.

The seasonal occurrence of species which were recorded as common at 1 or more study sites is shown in Table 2. From this it can be seen that although most of the common species had their season of greatest growth during late summer and autumn, many of these species were also present in smaller amounts during spring, though often at a lower level on the shore or in the sublittoral zone. Some species however were present only in late winter and spring, most conspicuously Sargassum binderi, S. latifolium and Cystoseira trinodis, and in addition Scinaia hatei and Coelarthrum opuntia. By contrast other species were present at all times between August and March, disappearing completely only during the height of summer (May and June). These species, which included Caulerpa cupressoides, C. racemosa and Halimeda tuna, principally accounted for the small amounts of algae present during the winter, although Ulva rigida was also present at that time but not during the spring.

\section{Quantitative data}

The qualitative pattern of seasonal growth is confirmed by data from quantitative sampling at 3 main stations during spring and autumn periods of growth (see Fig. 4). Across the 3 stations (1 at Mukalla, 2 at Sheher) total algal biomass (measured both as wet weight and as dry weight) in the middle and lower intertidal zones was usually of the order of 5 to 10 times greater in August than in February. In the upper intertidal zone no growth was apparent during February, while in August algal biomass in the upper intertidal was comparable to or greater than algal biomass in the lower intertidal during February. At all 3 stations and in both seasons (except at Motalla in spring) both wet and dry algal biomass increased sharply moving from upper to middle to lower intertidal zone. 
Table 1 . Occurrence of common algae (presence indicated by + ) in upper, mid-and lower intertidal zones at each of 3 main study stations, Khalf (Mukalla), Motalla (Sheher) and Hofra (Sheher)

\begin{tabular}{|c|c|c|c|c|c|c|c|c|c|}
\hline \multirow[t]{2}{*}{ Species } & \multicolumn{3}{|c|}{ Khalf (Mukalla) } & \multicolumn{3}{|c|}{ Motalla (Sheher) } & \multicolumn{3}{|c|}{ Hofra (Sheher) } \\
\hline & Upper & Mid & Lower & Uррег & Mid & Lower & Upper & Mid & Lower \\
\hline \multicolumn{10}{|l|}{ Chlorophyta } \\
\hline Enteromorpha flexuosa & & & & + & & & + & & \\
\hline Enteromorpha intestinalis & + & & & & & & & & \\
\hline Ulva fasciata & & & & + & + & & + & & \\
\hline Ulva lactuca & + & & & & & & & & \\
\hline Ulva rigida & & & & + & & & + & & \\
\hline Chaetomorpha antennina & + & & & & & & & & \\
\hline Chaetomorpha crassa & & & & + & & & + & & \\
\hline Cladophora prolifera & & & & & & & & + & \\
\hline Bryopsis pennata & & + & & & & & & & \\
\hline Caulerpa cupressoides & & & & & + & & & + & + \\
\hline Caulerpa mexicana & & & & & & & & & + \\
\hline Caulerpa racemosa & & & + & & & & & & + \\
\hline Codium tomentosum & & & + & & & + & & & \\
\hline Halimeda tuna & & & & & & + & & + & + \\
\hline Udotea indica & & & & & + & + & & + & + \\
\hline \multicolumn{10}{|l|}{ Phaeophyta } \\
\hline Dictyota divaricata & & & & & & + & & & + \\
\hline Padina gymnospora & & & & + & + & + & + & + & + \\
\hline Padina pavonica & & & & + & + & + & + & + & + \\
\hline Padina tetrastromicata & & & & + & + & + & + & + & + \\
\hline Spatoglossum asperum & & & + & & & + & & & \\
\hline Stoechospermum marginatum & & & & & & + & & & + \\
\hline Jolyna laminarioides & & & + & & & & & & \\
\hline Cystoseira trinodis & & & & & & + & & & + \\
\hline Sargassum binderi & & & & & & + & & & + \\
\hline Sargassum duplicatum & & & + & & & & & & \\
\hline Sargassum latifolium & & & & & & + & & & + \\
\hline Sargassopsis zanardinii & & & + & & & & & & \\
\hline \multicolumn{10}{|l|}{ Rhodophyta } \\
\hline Porphyra vietnamensis & + & + & & & & & & & \\
\hline Dermonema frappieri & + & + & + & & & & & & \\
\hline Galuxaura marginata & & & & & & & & & + \\
\hline Scinaia hatei & & & & & & & & & + \\
\hline Gelidiella acerosa & & & & & & & & + & + \\
\hline Grateloupla filicina & & & & & & + & & & \\
\hline Halymenia venusta & & & & & & & & & + \\
\hline Portieria hornemannii & & & & & + & + & & + & + \\
\hline Gracilaria canaliculata & & & & & & & & + & + \\
\hline Gracilania corticata & & & & & & + & & & + \\
\hline Gracilaria folinfera & & & & & + & + & & + & + \\
\hline Gracilaria textorij & & & & & + & + & & + & + \\
\hline Gracilaria verrucosa & & & & & + & + & & + & + \\
\hline Gracllariopsis lemaneiformis & & & & & + & + & & + & + \\
\hline Meristotheca papulosa & & & + & & & + & & & \\
\hline Sarconema filiforme & & + & + & & + & + & & + & + \\
\hline Sarconema scinaioides & & & & & & + & & & \\
\hline Soliena robusta & & & & & & + & & & \\
\hline Hypnea musiformis & & & & & + & + & & & + \\
\hline Hypnea pannosa & & & + & & & & & & \\
\hline Hypnea valentiae & & & & & + & + & & + & + \\
\hline Coelarthrum opuntia & & & & & & + & & & \\
\hline Champia globulifera & & & & & & + & & & \\
\hline Champia somalensis & & & & & & + & & & \\
\hline Centroceras claviulatum & & + & + & & + & + & & + & + \\
\hline Ceramium flaccidum & & & & & & & & & + \\
\hline Dasya baillouviana & & & & & + & + & & + & + \\
\hline Chondria dasyphylla & & & & & & & & & + \\
\hline Laurencia obtusa & & & + & & & & & & \\
\hline Laurencia papillosa & & & & & + & + & & + & + \\
\hline Laurencia pinnatifida & & & + & & & & & & \\
\hline Melanothamnus somalensis & & + & + & & & & & & \\
\hline Polysiphonia crassicolis & & & & & & & & & + \\
\hline
\end{tabular}


Table 2. Occurrence of common algae (presence indicated by + ) at different times of year. Column headings indicate months (N: November; D: December; J: January; F: February; etc.)

\begin{tabular}{|c|c|c|c|c|c|c|c|c|c|c|c|c|}
\hline \multirow[t]{2}{*}{ Species } & \multicolumn{3}{|c|}{ Winter } & \multicolumn{3}{|c|}{ Spring } & \multicolumn{3}{|c|}{ Summer } & \multicolumn{3}{|c|}{ Autumn } \\
\hline & $\mathrm{N}$ & $\mathrm{D}$ & $\mathrm{J}$ & $\mathrm{F}$ & $M$ & A & M & $\mathrm{J}$ & $\mathrm{J}$ & A & $\mathrm{S}$ & O \\
\hline \multicolumn{13}{|l|}{ Chlorophyta } \\
\hline Enteromorpha flexuosa & & & & & & & & & + & + & + & + \\
\hline Enteromorpha intestinalis & & & & & & & & & + & + & + & + \\
\hline Ulva fasciata & & & & & & & & & + & + & + & + \\
\hline Ulva lactuca & & & & & & & & & + & + & + & + \\
\hline Ulva rigida & + & + & & & & & & & & + & + & + \\
\hline Chaetomorpha antennina & & & & & & & & & & + & + & + \\
\hline Chaetomorpha crassa & & & & & & & & & & + & + & + \\
\hline Cladophora prolifera & & & + & + & & & & & & + & + & + \\
\hline Bryopsis pennata & & & & & & & & & & + & + & + \\
\hline Caulerpa cupressoides & + & + & + & + & + & & & & & + & + & + \\
\hline Caulerpa mexicana & & & & & & & & & & + & + & + \\
\hline Caulerpa racemosa & + & + & + & + & + & & & & & + & + & + \\
\hline Codium tomentosum & & & + & + & & & & & & + & + & + \\
\hline Halimeda tuna & + & + & + & + & + & & & & & + & + & + \\
\hline Udotea indica & & & + & + & & & & & & + & + & + \\
\hline \multicolumn{13}{|l|}{ Phaeophyta } \\
\hline Dictyota divaricata & & & + & + & & & & & & + & + & + \\
\hline Padina gymnospora & & & + & + & & & & & & + & + & + \\
\hline Padina pavonica & & & & & & & & & & + & + & + \\
\hline Padina tetrastromatica & & & + & + & & & & & & + & + & + \\
\hline Spatoglossum asperum & & & + & + & & & & & & + & + & + \\
\hline Stoechosperum marginatum & & & + & + & + & & & & & + & + & + \\
\hline Jolyna laminarioides & & & & & & & & & & + & + & + \\
\hline Cystoseira trinoidis & & + & + & + & + & + & & & & & & \\
\hline Sargassum binderi & & + & + & + & + & + & & & & & & \\
\hline Sargassum duplicatum & & & & & & & & & & + & + & + \\
\hline Sargassum latifolium & & + & + & + & + & + & & & & & & \\
\hline Sargassopsis zanardinii & & & & & & & & & & + & + & + \\
\hline \multicolumn{13}{|l|}{ Rhodophyta } \\
\hline Porphyra vietnamensis & & & & & & & & & & + & + & + \\
\hline Dermonema frappieri & & & & & & & & & & + & + & + \\
\hline Galaxaura marginata & & & + & + & & & & & & + & + & + \\
\hline Scinaia hatei & & & + & + & + & & & & & & & \\
\hline Gelidiella acerosa & & & + & + & & & & & & + & + & \\
\hline Grateloupia filicina & & & + & + & & & & & & + & + & + \\
\hline Halymenia venusta & & & + & + & & & & & & + & + & \\
\hline Portieria hornemannii & & & + & + & & & & & & + & + & + \\
\hline Gracilaria canaliculata & & & + & + & & & & & & + & + & \\
\hline Gracilaria corticata & & & + & + & & & & & & + & + & + \\
\hline Gracilaria foliifera & & & + & + & + & & & & & + & + & + \\
\hline Gracilaria textorii & & & & & & & & & & + & + & + \\
\hline Gracilaria verrucosa & & & + & + & + & & & & & + & + & + \\
\hline Gracilariopsis lemaneiformis & & & & & & & & & & + & + & + \\
\hline Sarconema filforme & & & + & + & + & & & & & + & + & + \\
\hline Sarconema scinaioides & & & & & & & & & & + & + & + \\
\hline Meristotheca papulosa & & & + & + & & & & & & + & + & + \\
\hline Solieria robusta & & & + & & & & & & & + & + & + \\
\hline Hypnea musiformis & & & + & + & + & & & & & + & + & + \\
\hline Hypnea pannosa & & & & & & & & & & + & + & + \\
\hline Hypnea valentiae & & & + & + & + & & & & & + & + & + \\
\hline Coelarthrum opuntia & & & + & + & & & & & & & & \\
\hline Champia globulfera & & & & & & & & & & + & + & \\
\hline Champia somalensis & & & & & & & & & & + & + & + \\
\hline Centroceras claviulatum & & & + & + & + & & & & & + & + & + \\
\hline Ceramium flaccidum & & & + & + & + & & & & & + & + & \\
\hline Dasya baillouvana & & & + & + & & & & & & + & + & + \\
\hline Chondria dasyphylla & & & + & + & & & & & & + & + & \\
\hline Laurencia obtusa & & & + & + & & & & & & + & + & + \\
\hline Laurencia papillosa & & & + & + & & & & & & + & + & + \\
\hline Laurencia pinnatifida & & & & & & & & & & + & + & + \\
\hline Melanothamnus somalensis & & & & & & & & & & + & + & + \\
\hline Polysiphonia crassicolıs & & & + & + & & & & & & + & + & + \\
\hline
\end{tabular}


An analysis of variance (SPSS-X) confirms that most of these trends and differences are statistically significant. Analysis of variance in wet weight by site, season and zone shows variances due to zone and season to be highly significant $(F=11.77, \mathrm{p}<0.0001$ and $F=104.51, \mathrm{p}<0.001$ respectively), and variance due to site to be also significant, though less so $(F=4.96, \mathrm{p}<0.01)$. These data show a significant interaction between site and season $(F=8.44, \mathrm{p}<0.001)$ and between site and zone $(F=4.13, \mathrm{p}<0.01)$, but not, perhaps surprisingly, between zone and season $(F=2.31, p>0.1)$. Using dry weight, variances with zone and season are again highly significant $(F=10.56, \mathrm{p}<0.001$ and $F=77.80, \mathrm{p}<0.001$ respectively), but variance with site is not significant $(F=$ $1.38, \mathrm{p}<0.25$ ). With dry weight, interaction between zone and season is just significant $(F=3.65, \mathrm{p}<0.05)$, but other interactions are not so.

Also shown in Fig. 4 are the numbers of species recorded in the quantitative samples (quadrats) at each of the 3 main study sites at each level on the shore. Species number increased going from Khalf (Mukalla) to Motalla (Sheher) to Hofra (Sheher), and also increased moving from upper shore to midshore to lower shore.

Table 3 shows the mean wet weights per quadrat of the principal species obtained in these quantitative samples at each level on the shore. In February, at all 3 stations, no collectable algae were present in the quadrats on the upper shore. At the same time in the middle intertidal Sarconema filiforme was the most widespread species. This was the only species present in the quadrats in this zone at Khalf, but at both Sheher stations Laurencia papillosa was more abundant, and at Hofra the greatest biomass was of Gracilaria corticata. On the lower shore at Khalf $S$. filliforme remained abundant but the greater biomass was of Laurencia obtusa. By contrast at Motalla in February the lower intertidal quadrats were dominated by Padina species, while at Hofra 7 species were abundant, the greatest mean biomass being of Laurencia papillosa, which was also abundant in the mid-shore quadrats at that site.

In August a greater growth of more species was apparent at all sites and all levels on the shore. On the upper shore Enteromorpha intestinalis and Ulva fasciata were most abundant in quadrats at Khalf, but at Motalla and Hofra these are replaced by Enteromorpha flexuosa and Ulva lactuca. In mid-shore quadrats at Khalf the greatest mean biomass was of
Melanothamnus somalensis, at Motalla Padina tetrastromatica and Ulva lactuca were most abundant, and at Hofra Centrocerus clavulatum, Gracilariopsis lemaneiformis and Enteromorpha flexuosa.

On the lower shore at Khalf the species most abundant in quadrats were the same as on the middle shore, together with Centrocrus clavulatum. By contrast, at both Sheher sites (Motalla and Hofra) Gracilaria species become the most abundant forms in lower shore quadrats, with other abundant species including Padina gymnospora, Caulerpa racemosa, Laurencia papillosa and Halimeda tuna at both sites, together with Ulva lactuca at Hofra, and Enteromorpha flexuosa, Padina tetrastromatica and Gracilariopsis lemaneiformis at Motalla.

Most species recorded in the quadrats were abundant either in February or in August, but not both (Table 3). The greater number were abundant in August, i.e. during the period of the southwest monsoon, and others were abundant only in February, i.e. during the period of the northeast monsoon. Only a few species (Laurencia papillosa, Padina gymnospora, Halimeda tuna and Gracilaria foliifera) were recorded as abundant in quadrats during both spring and autumn 
Table 3. Mean biomass (wet weight) of principal macroalgal species collected from quadrats $\left(1 \mathrm{~m}^{2}\right)(\mathrm{n}=6)$ at different levels on the shore during the northeast (February) and southwest (August) monsoons at each of 3 main study stations, Khalf (Mukalla), Motalla (Sheher) and Hofra (Sheher)

\begin{tabular}{|c|c|c|c|c|c|c|c|c|c|c|c|c|}
\hline \multirow[t]{3}{*}{ Species } & \multicolumn{6}{|c|}{ February } & \multicolumn{6}{|c|}{ August } \\
\hline & \multicolumn{2}{|c|}{ Khalf } & \multicolumn{2}{|c|}{ Motalla } & \multicolumn{2}{|c|}{ Hofra } & \multicolumn{2}{|c|}{ Khalf } & \multicolumn{2}{|c|}{ Motalla } & \multicolumn{2}{|c|}{ Hofra } \\
\hline & $\bar{x}$ & $\mathrm{SE}$ & $\bar{x}$ & SE & $\bar{x}$ & $\mathrm{SE}$ & $\bar{x}$ & $\mathrm{SE}$ & $\bar{x}$ & SE & $\bar{x}$ & SE \\
\hline \multicolumn{13}{|l|}{ Upper shore } \\
\hline Ulva fasciata & & & & & & & 355.5 & 163.3 & & & & \\
\hline Ulva lactuca & & & & & & & & & 126.4 & 78.2 & 152 & 46.7 \\
\hline Enteromorpha intestinalis & & & & & & & 525 & 402.8 & & & & \\
\hline Enteromorpha flexuosa & & & & & & & & & 79.2 & 384.9 & 20 & 12.6 \\
\hline Dermonema frappieri & & & & & & & 60 & - & & & & \\
\hline Padina gymnospora & & & & & & & & & 48.8 & 31.7 & & \\
\hline Padina tetrastromatica & & & & & & & & & 177.6 & 158.3 & & \\
\hline \multicolumn{13}{|l|}{ Middle shore } \\
\hline Sarconema filiforme & 75 & 70 & 18 & 15.7 & 75.2 & 39.9 & & & & & & \\
\hline Laurencia papillosa & & & 54 & 50.8 & 100 & 64,4 & & & & & & \\
\hline Padina sp. & & & 25.3 & 15.2 & & & & & & & & \\
\hline Gracilaria corticata & & & & & 166 & 61.6 & & & & & & \\
\hline Caulerpa cupressoides & 25.6 & - & & & & & & & & & & \\
\hline Caulerpa racemosa & & & & & 20 & - & & & & & & \\
\hline Rhodomenia sp. & & & & & 32 & 28.1 & & & & & & \\
\hline Ulva fasciata & & & & & & & 157 & 134.9 & & & & \\
\hline Ulva lactuca & & & & & & & & & 628 & 265.5 & & \\
\hline Enteromorpha flexuosa & & & & & & & & & & & 108 & 66.2 \\
\hline Dermonema frappieri & & & & & & & 157 & 110.3 & & & & \\
\hline Padina gymnospora & & & & & & & & & & & 45.6 & 40.7 \\
\hline Padina tetrastromatica & & & & & & & & & 443.2 & 177.7 & 60.8 & 55.9 \\
\hline Melanothamnus somalensis & & & & & & & 895 & 822.1 & & & & \\
\hline Gracilaria textorii & & & & & & & & & & & 56.8 & - \\
\hline Centrocerus clavulatum & & & & & & & & & & & 200 & 122.4 \\
\hline Gracilariopsis lemaneiformis & & & & & & & & & & & 139.5 & - \\
\hline Gracilaria verrucosa & & & & & & & & & & & 24 & - \\
\hline \multicolumn{13}{|l|}{ Lower shore } \\
\hline Sarconema filiforme & 64 & 50.9 & & & 85.3 & 39.6 & & & & & & \\
\hline Laurencia obtusa & 276.8 & 134 & & & & & & & & & & \\
\hline Laurencia papillosa & & & & & 167.3 & 30.7 & & & 124 & 71.9 & 44 & 31.2 \\
\hline Codium tomentosum & 56 & - & & & & & & & & & & \\
\hline Padina gymnospora & & & 29.3 & 18.6 & & & & & 220 & 115.5 & 80 & - \\
\hline Padina sp. & & & 18.66 & - & & & & & & & & \\
\hline Halimeda tuna & & & 45.3 & - & & & 24 & - & 30 & - & & \\
\hline Gracilaria corticata & & & & & 77.3 & 43.1 & & & & & & \\
\hline Rhodymenia sp. & & & & & 25.3 & 18.5 & & & & & & \\
\hline Stoechosperum marginatum & & & & & 23.3 & - & & & & & & \\
\hline Laurencia sp. & & & & & 16.6 & - & & & & & & \\
\hline Gracilaria foliifera & & & & & 30 & - & & & 380 & 318.9 & & \\
\hline Gracilaria verrucosa & & & & & & & & & & & 337.6 & 229.6 \\
\hline Ulva fasciata & & & & & & & 33 & - & & & & \\
\hline Ulva lactuca & & & & & & & & & 36 & 22.2 & & \\
\hline Enteromorpha flexuosa & & & & & & & & & & & 195 & 172.5 \\
\hline Dermonemd frappieri & & & & & & & 100 & - & & & & \\
\hline Melanothamnus somalensis & & & & & & & 1930 & 769.3 & & & & \\
\hline Padina tetrastromatica & & & & & & & & & & & 72 & - \\
\hline Centrocerus clavulatum & & & & & & & 155 & 148.4 & & & & \\
\hline Caulerpa racemosa & & & & & & & & & & & 124 & 76 \\
\hline Gracilariopsis lemaneiformis & & & & & & & & & & & 268 & 263 \\
\hline Gracilaria textorii & & & & & & & & & & & 52 & - \\
\hline
\end{tabular}

\section{Inorganic nutrients}

The pattern of seasonal variation during 1989 in mean seawater concentrations of phosphate-phosphorus $\left(\mathrm{PO}_{4}-\mathrm{P}\right)$ and silicate-silicon $\left(\mathrm{SiO}_{4}-\mathrm{Si}\right)$ at the 3 main sampling stations can be described as follows. Mean $\mathrm{PO}_{4}-\mathrm{P}$ concentrations were of the order of $0.5 \mu \mathrm{g}$-at. $\mathrm{I}^{-1}$ during January and February, but increased during March to over $1.75 \mu \mathrm{g}$-at. $\mathrm{l}^{-1}$ before declining in April to less than $0.2 \mu \mathrm{g}$-at. $\mathrm{l}^{-1}$. Highest mean levels 


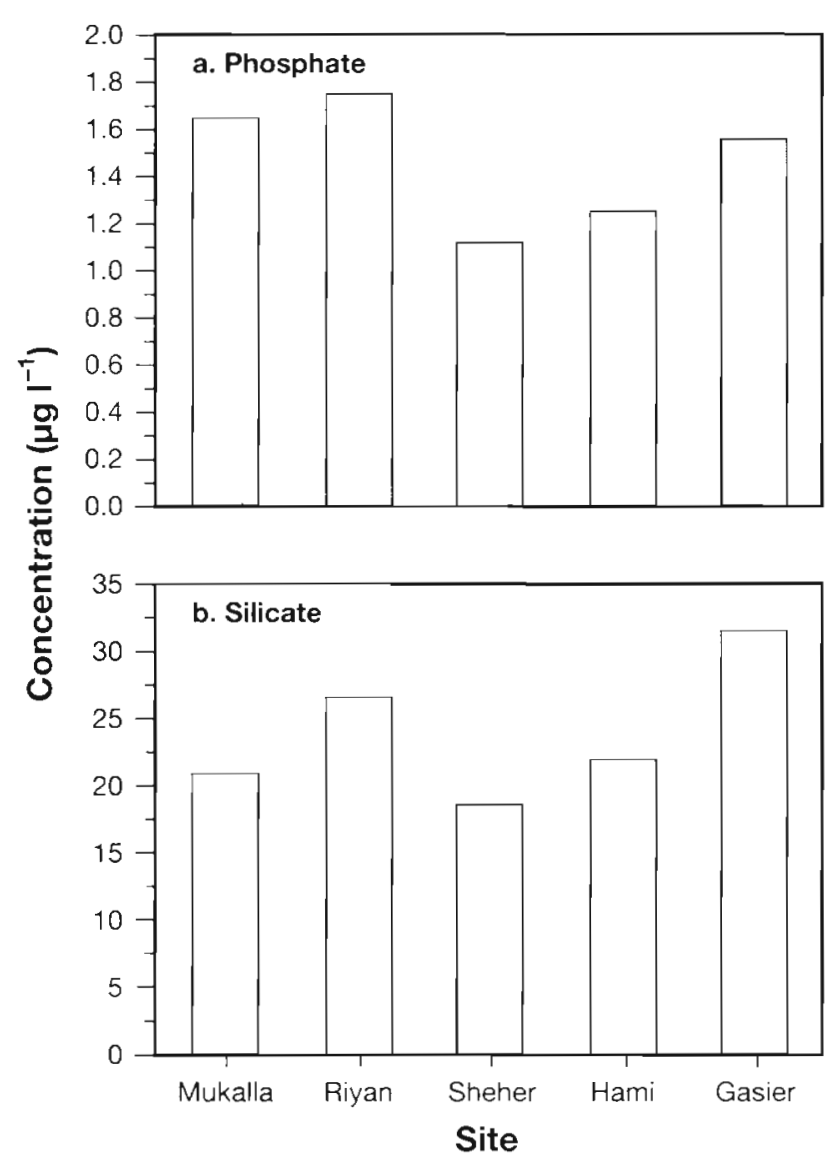

Fig. 5. Mean (a) phosphate and (b) silicate concentrations $(n=3)$ recorded near shore in each of the 5 study areas within a few days in August 1988

(2.87 $\mu$ g-at. $\mathrm{l}^{-1}$ ) were recorded during July. Mean levels remained relatively high until September $\left(1.95 \mu \mathrm{g}\right.$-at. $\left.\mathrm{I}^{-1}\right)$, after which they showed a slow decline to the low levels recorded during January and February.

Mean $\mathrm{SiO}_{4}$-Si levels show a comparable pattern with relatively low levels of 6 to $8 \mu \mathrm{g}$-at. $\mathrm{l}^{-1}$ in JanuaryFebruary, a first peak of almost $30 \mu \mathrm{g}$-at. $1^{-1}$ in March, a second slightly smaller peak in July-August, followed by a second decline after September back to a mean level of less than $8 \mu \mathrm{g}$-at. $1^{-1}$. The pattern for $\mathrm{SiO}_{4}$-Si differed from that for $\mathrm{PO}_{4}-\mathrm{P}$ principally in that the peak mean level of $\mathrm{SiO}_{4}$-Si recorded in the autumn (23.69 $\mu \mathrm{g}$-at. $\mathrm{l}^{-1}$ ) was lower than that recorded in spring (29.01 $\mu \mathrm{g}$-at. $1^{-1}$ ). A comparison of mean nutrient levels recorded during spring and autumn at each of the 3 main study sites shows no consistent difference between these 3 sites.

To check for a possible geographical trend across a wider range of sites, means for samples taken within a few days of each other at all 5 study areas in August 1988 (near the centre of the upwelling period) were compared (see Fig. 5). The same trend is apparent in both mean $\mathrm{PO}_{4}-\mathrm{P}$ and mean $\mathrm{SiO}_{4}$-Si concentration in that, going from west to east, they increased going from Mukalla to Riyan, dropped to their lowest level at Sheher, and then increased again moving further east to Hami and then to Gasier.

\section{Surface water temperature}

Variation in mean surface seawater temperature over all study sites showed a pattern essentially complementary to seasonal variation in inorganic nutrients. Lowest mean temperatures were recorded between July $\left(24.5^{\circ} \mathrm{C}\right)$ and September $\left(23.4^{\circ} \mathrm{C}\right)$, when highest mean phosphate levels were recorded. A second smaller drop in mean seawater temperature was recorded in February $\left(25.8^{\circ} \mathrm{C}\right)$ when a second smaller peak in mean $\mathrm{PO}_{4}$-P level also occurred. This smaller drop in mean seawater temperature was followed by a marked increase in temperature to $28.0^{\circ} \mathrm{C}$ in March. The 2 highest individual seawater temperature readings during 1989 were both recorded in March $\left(29^{\circ} \mathrm{C}\right)$, and the lowest in September $\left(20^{\circ} \mathrm{C}\right)$. although more extreme temperatures have been recorded on other occasions. Differences in mean seawater temperatures between sites were not statistically significant.

The pattern of seasonal variation in seawater temperature is most clearly shown by a comprehensive set of readings taken at a single site (Motalla) over 1988 (see Fig. 6). Surface temperature increased to a peak of 30 to $31^{\circ} \mathrm{C}$ during the period April to June. This was followed by a dramatic fall to between 19 and $22^{\circ} \mathrm{C}$ observed during July. Following a second minimum of $21^{\circ} \mathrm{C}$ in September, seawater temperatures then

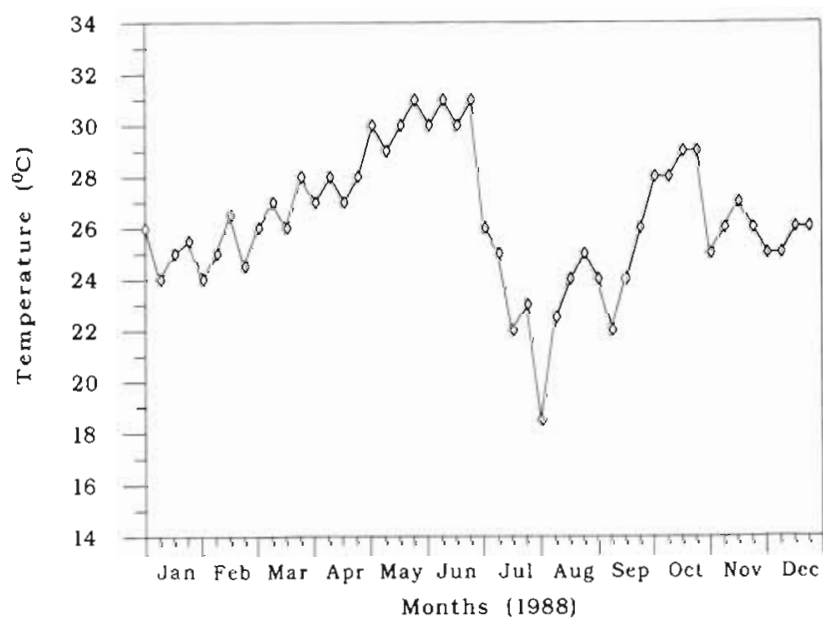

Fig. 6. Near-shore surface water temperature taken at weekly intervals throughout 1988 at Motalla, Sheher 
recovered to a second maximum of $29^{\circ} \mathrm{C}$ in October before declining to the range of 24 to $26^{\circ} \mathrm{C}$ observed during the period November to February.

\section{Climatic data}

Climatological data, based on records obtained at Riyan airport, are given in Fig. 7. Mean daily air temperatures increased from a minimum in January (mean $24.2^{\circ} \mathrm{C}$ ) to a maximum in June (mean $31.0^{\circ} \mathrm{C}$ ) before declining again to the January level. Data on mean cloud cover showed a low but variable cover throughout the year, with small peaks in February, April and June, and a sustained low from October to January.

Records of wind strength and direction, in contrast to cloud cover records, showed a very marked annual pattern. The pattern is consistent with the annual occurrence of northeast and southwest monsoons. This is illustrated in Fig. 7 by the pattern of variation in the mean percentage of observations, month by month, in which detectable wind was from the south, southwest, or west. This varied between 1 and $8 \%$ over most of the year, but between May and July increased markedly to between 24 and $29 \%$.

Relative humidity (Fig. 7) was moderately high throughout the year, but nevertheless showed a consistent annual pattern. There was a broad peak of 73 to $77 \%$ relative humidity from March to May, and a sharper peak of up to $79 \%$ centred on September, while minimum values of 64 to $66 \%$ occurred between November and January. The drop in relative humidity between May and September coincides with the period of winds from the south to west, i.e. with the southwest monsoon.

\section{DISCUSSION}

Although previous papers (Banaimoon 1986, 1988a, b) have described the occurrence on rocky shores at different sites in the Hadramout of many of the species reported here, the present study presents the first comprehensive account of the general ecology of intertidal macroalgal assemblages of the southern coast of Yemen. It is evident that, as on other temperate and tropical rocky shores experiencing a significant tide (Lewis 1964, Stephenson \& Stephenson 1972), there is a marked zonation of species across the shore. Similar macroalgal assemblages showing a comparable zonation have been described for rocky shores on the neighbouring coast of southern Oman by Barratt et al. (1984, 1986), who also described sublittoral communities dominated in shallow water by the large fucalean alga Sargassopsis zanardinii (see Nizamud-

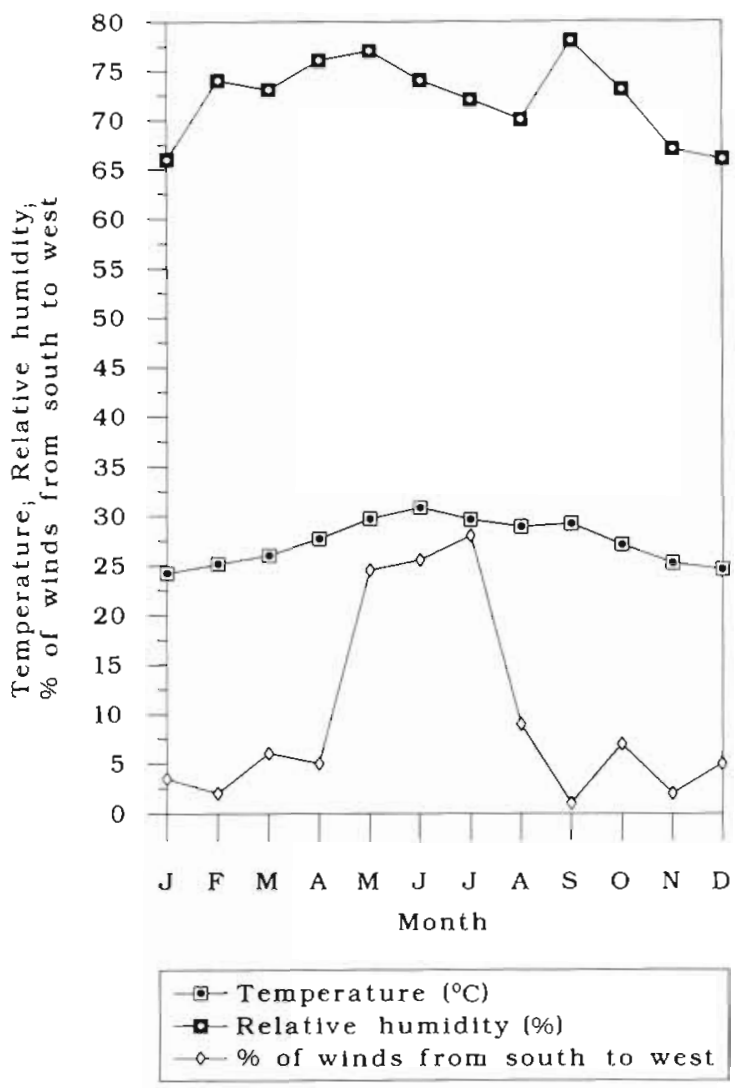

Fig. 7. Monthly variation in mean daily air temperature, mean relative humidity and mean percentage incidence of winds from the south, southwest and west combined, recorded at Riyan Airport during 1988 to 1990

din et al. 1993) and in deeper water by the kelp Ecklonia radiata.

The precise identification of many of the Oman species has yet to be confirmed, but it is evident that most of the species dominating the intertidal zone are the same as those reported here from Yemen. Barratt et al. (1984, 1986) described more exposed steep rocky shores as being dominated by a dense cover of Ulva spp. (fasciata?), Endarachne binghamiae (= Jolyna Iaminarioides), (?) Pterosiphonia cloiophylla (= Melanothamnus somalensis) and (?)Suhria vittata, usually occurring in that order moving from upper to lower shore, together with Chaetomorpha spp and Porphyra sp. (vietnamensis?). More sheltered sites are described as being dominated by 2 species of Ulva (lactuca? fasciata?) and (?)Dermonema frapperi. Synonymy given in brackets is presumed identification with updated species names used in the present study and suggested as a result of inspection of the Oman material. All save (?) S. vittata, whose identity remains uncertain, correspond to species recognised here as dominant on corresponding shores in southern Yemen. 
Barratt et al. $(1984,1986)$ also describe on limestone shores an intertidal rocky platform dominated by cushion-forming species including species of genera such as Caulerpa, Dictyota, Gelidium, Hypnea, and Laurencia, often accompanied by more erect forms of Padina, Gracilaria, Galaxaura, Chondrococcus and Sargassum. All are genera also recorded in the present study as common on rocky shores in the Hadramout.

In both southern Oman and southern Yemen the most conspicuous feature of the intertidal macroalgal assemblage is the dense and abundant growth that develops during the period of the southwest monsoon. There are no comparable biomass figures from southern Oman, but from detailed visual inspection this monsoonal growth appears generally greater in the Dhofar region of southern Oman (R. F. G. Ormond pers. obs.), and is clearly at a peak in the Mirbat and Sudah area within southern Oman (Barratt et al. 1984, 1986). Nutrient data from Oman (Savidge et al. 1986, 1990), supported by data from the present study, suggest that this dense growth during the period of the southwest monsoon is associated with the high levels of nutrients recorded at this time. Apparent differences in intertidal biomass between regions support this interpretation. Upwelling during the southwest monsoon is centred on the Arabian coast east of Ras Fartak (a little west of the south Yemen/south Oman border) and is at its most intense between Ras Mirbat and Ras Sharbitat in Oman (Currie 1992). This is the section of coast centred on Mirbat and Sudah (Fig. 1). Thus development of this intertidal algal assemblage is associated with the period of upwelling, and is greatest on that part of the coast where upwelling is most intense.

In fact data from the present Hadramout study suggest the possibility of a temporal displacement between the peak of the monsoon, which is in June and July (Fig. 7), maximum nutrient levels, which are in July and August, and densest algal growth, which is in August and September. This phasing could perhaps be understood in terms of the delay required for the southwesterly winds to generate sufficient upwelling to bring nutrient-rich water to the Hadramout coast, and the subsequent time required for growth of algae once adequate nutrients become available. A time lag between peak ambient nutrient concentrations and maximum macroalgal growth is common on temperate shores (Gagne et al. 1982, Asare \& Harlin 1983, Stromgren 1986, Carlson 1991).

Also supportive of the view that nutrient supply is critical is the lack of correlation of peak algal growth with factors that have been suggested as important in influencing seasonal variation in algal growth in other non-upwelling tropical locations (Gessner \& Hammer 1967, Taylor \& Bernatowicz 1969, Croley \& Dawes
1970, Santelices 1977, Moorjani 1979, Bryceson 1982), and which might have been suspected of being significant in the present case. The period of greatest intertidal algal development (August to September) does not correspond (Fig. 7) with minimum air temperature (December to February), maximum air temperature (May to July), highest relative humidity (September to October) or greatest cloud cover (February to June). On the other hand maximum air temperatures during May and June seem likely to be a factor leading to the complete lack of intertidal macroalgae at that time.

It is well established that, given adequate illumination, inorganic nutrient levels are the factor most normally controlling the growth of marine algae (Lapointe \& Tenore 1981, Lapointe et al. 1984). Further, in an area of seasonal upwelling in Oregon, USA, Fujita et al. (1989) showed that growth of Ulva rigida appears to be limited by the supply of inorganic nitrogen prior to the commencement of upwelling. Thus our observations in southern Yemen are comparable with conclusions concerning the role of nutrients elsewhere. However, while inorganic nitrogen rather than phosphorus has generally been considered the limiting nutrient in temperate coastal waters (Topinka \& Robbins 1976 , Chapman \& Craigie 1977, Hanisak 1979, Gagne et al. 1982, Gerard 1982, Davison et al. 1984) it has recently been suggested that phosphorus rather than nitrogen may be the limiting nutrient in some tropical and subtropical waters (Lapointe 1987, 1989, Lapointe et al. 1992). Whether in a tropical upwelling area such as southern Arabia growth of all or most macroalgal species is controlled by availability of inorganic nitrogen or inorganic phosphorus remains to be determined.

While maximum macroalgal biomass occurs during the autumn, the separate period of a smaller amount of growth that occurs during the spring (January to March) is also of interest. This coincides with records of nutrient levels that, while not as high as those observed in July and August during the southwest monsoon, are higher than at other times of year. This smaller peak coincides with and could be associated with the northeast monsoon. Further study is required to assess whether this spring growth is due to this wind, which may possibly generate, at least in some areas, slightly elevated nutrient levels, or whether it is due to other factors. In this context it is of interest that some of the species most conspicuous during the spring (Sargassum binderi, S. latifolium, Cystoseira trinodis, Caulerpa cupressoides, C. racemosa and Halimeda tuna) are different from those which dominate during the autumn. These species are all ones which are conspicuous throughout other parts of the western Indian Ocean where they may be able to dominate under conditions of lower nutrient maxima typically encountered elsewhere in that region. 
Even within the present study area there appear to be some slight differences between sites in the amount of algal growth. Biomass is slightly greater at the western site of Mukalla, while species richness increases markedly as one moves eastwards to Hofra and Motalla. These differences might be explained in terms of small differences in intensity of upwelling, perhaps due to local differences in submarine topography, as implicated on the southern coast of Oman (Savidge et al. 1990). However a more important difference seems likely to relate to the form of the shore which is in turn due to the character of the rock of which the shore is composed, a factor also emphasised by Barratt et al. $(1984,1986)$. The igneous rocks at Khalf and Gasier (Fig. 2a) are steep and fissured. On the upper and mid-shore they are dominated by bivalves and gastropods which find hold or shelter among the crevices. By contrast the limestone rock at Sheher, Al-Dubbah and Hami (Fig. 2b) has been eroded to create rough intertidal platforms; these become covered by shoreward-moving sand during the calmer winter period and, probably as a result, have only small faunal populations. When uncovered by wave action during the southwest monsoon there is a greater proportion of substrate available for colonisation and grazing pressure is less than on the igneous shores. This contrasts with the situation in Dhofar where the intertidal limestone platforms are not covered by sand during winter and a dense algal turf develops which is subject to intense grazing by echinoids and herbivorous fish (Barratt et al. 1986).

In summary, a luxuriant growth of macroalgae develops on intertidal rocks in the Hadramout region of southern Yemen during the southwest monsoon. The dominant species are similar to those reported from comparable communities in the Dhofar region of southern Oman. The evidence supports the interpretation that this growth is associated with high nutrient levels due to seasonal upwelling along the southern Arabian coast, rather than with any other oceanographic or climatic factor. During spring there is a smaller peak in algal growth involving some different species that are prevalent in other parts of the Indian Ocean region. Our observations are not incompatible with those other studies (see 'Introduction') that suggest that seasonal variation in the growth of these species in non-upwelling tropical areas may be due to factors other than nutrient supply.

Acknowledgements. We thank Lynne Barratt, Doug Moncur, Duncan Reavey, Graham Savidge, Michael Wynne and several anonymous referees for advice, and the Kuwait Institute for Scientific Research (KISR) and the Universities of Aden and Sana'a for their support and assistance.

Appendix. Full list of algal species (presence indicated by + ) recorded in the intertidal zone in each of the 5 study areas, Mukalla (Mk), Al-Dubbah (AD), Sheher (Sh), Hami (Hm), and Gasier (Gs), on the Hadramout coast of southern Yemen

\begin{tabular}{|c|c|c|c|c|c|c|}
\hline Species & Authority & Mk & $\mathrm{AD}$ & Sh & $\operatorname{Hm}$ & Gs \\
\hline \multicolumn{7}{|l|}{ Chlorophyta } \\
\hline Enteromorpha clathrata & (Roth) Greville & & + & + & & \\
\hline Enteromorpha compressa & (Linnaeus) Nees & & & + & & \\
\hline Enteromorpha flexuosa & (Wulfen) J. Agardh & & + & + & + & \\
\hline Enteromorpha intestinalis & (Linnaeus) Nees & + & & & & + \\
\hline Ulva fasciata & Delile & + & & & & + \\
\hline Ulva lactuca & Linnaeus & & + & + & + & \\
\hline Ulva cf. pertusa & Kjellman & & & + & & \\
\hline Ulva rigida & C. Agardh & & + & + & + & \\
\hline Chaetomorpha antennina & (Bory de Saint-Vincent) Kützing & + & & & & + \\
\hline Chaetomorpha aerea & (Dillwyn) Kützing & & & + & & \\
\hline Chaetomorpha capillaris & (Kützing) Borgesen & & & + & & \\
\hline Chaetomorpha crassa & (C. Agardh) Kützing & & + & + & + & \\
\hline Cladophora koiei & Borgesen & & + & + & & \\
\hline Cladophora nitellopsis & Borgesen & & & + & + & \\
\hline Cladophora prolifera & (Roth) Kützing & & & + & & \\
\hline Cladophora sericoides & Borgesen & & & + & & \\
\hline Cladophora vagabunda & (Linnaeus) van den Hoek & & + & + & + & \\
\hline Boodlea composita & (Harvey) Brand & & & + & + & \\
\hline Valoniopsis pachynema & (Martens) Borgesen & & & + & & \\
\hline Bryopsis pennata & Lamouroux & + & & & & \\
\hline Bryopsis pennata & (Lamouroux) & & & & & \\
\hline var. leprieurij & (Kützing) Collins \& Hervey & + & & & & \\
\hline Bryopsis pennata & (Lamouroux) & & & & & \\
\hline var. secunda & (Harvey) Collins \& Hervey & + & & & & \\
\hline
\end{tabular}


Appendix (continued)

\begin{tabular}{|c|c|c|c|c|c|c|}
\hline Species & Authority & $M k$ & $A D$ & Sh & $\mathrm{Hm}$ & Gs \\
\hline Caulerpa cupressoides & (Vahl) C. Agardh & & + & + & + & \\
\hline Caulerpa cupressoides & (Vahl) C. Agardh & & & & & \\
\hline var. lycopodium & Weber-van Bosse & & & + & & \\
\hline Caulerpa fastigiata & Montagne & & & + & + & \\
\hline Caulerpa racemosa & (Forsskål) J. Agardh & + & + & + & + & \\
\hline Caulerpa racemosa & (Forsskål) J. Agardh & & & & & \\
\hline var. peltata & (Lamouroux) Eubank & & + & + & + & \\
\hline Caulerpa racemosa & (Forsskål) J. Agardh & & & & & \\
\hline var. macrophysa & (Sonder ex Kützing) Taylor & & & + & & \\
\hline Caulerpa racemosa & (Forsskål) J. Agardh & & & & & \\
\hline var. turbinata & (J. Agardh) Eubank & & & + & & \\
\hline Caulerpa mexicana & Sonder ex Kützing & & + & + & + & \\
\hline Caulerpa scalpelliformis & (R. Brown ex Turner) C. Agardh & & & + & + & \\
\hline Caulerpa sertularioides & (S. G. Gmelin) Howe & & + & + & + & \\
\hline Caulerpa serrulata & (Forsskål) J. Agardh & & & + & & \\
\hline Codium elongatum & Auctorum & + & & & & \\
\hline Codium iyengarii & Borgesen & + & & & + & \\
\hline Codium tomentosum & Auctorum & + & & + & + & + \\
\hline Codium sp. (flattened) & & & & + & & \\
\hline Halimeda tuna & (Ellis \& Salander) Lamouroux & + & + & + & + & + \\
\hline Halimeda papyracea & Zanardini & & + & + & + & \\
\hline Halimeda cf. renschii & Hauck & + & & & + & \\
\hline Udotea indica & A. Gepp \& E. S. Gepp & & + & + & + & \\
\hline Udotea palmetta & DeCaisne & & & + & & \\
\hline Struvea anastomosans & (Harvey) Piccone \& Grumour in Piccone & & & + & & \\
\hline Struvea sp. & & & & + & & \\
\hline Siphonocladus tropicus & (P. \& H. Crouan in Schramm \& Maze) J. Agardh & & & + & & \\
\hline Chlorodesmis hildebrandtii & A. Gepp \& E. S. Gepp & + & & & & \\
\hline \multicolumn{7}{|l|}{ Phaeophyta } \\
\hline Dictyopteris delicatula & Lamouroux & & + & + & + & \\
\hline Dictyota ceylanica & Kützing & & & + & & \\
\hline Dictyota divaricata & Lamouroux & & + & + & + & \\
\hline Dictyota dichotoma & (Hudson) Lamouroux & & & & + & \\
\hline Padinia gymnospora & (Kützing) Sonder & & + & + & + & \\
\hline Padina tetrastromatica & Hauck & & + & + & + & \\
\hline Padina pavonica & (Linnaeus) Thivy & & + & + & + & \\
\hline Padina sp. 1 ( 4 cell thick) & & & + & & & \\
\hline Padina sp. 2 ( 6 cell thick) & & & & & + & \\
\hline Padina sp. 3 ( 5 cell thick) & & & & & + & \\
\hline Spatoglossum asperum & J. Agardh & + & + & + & + & \\
\hline Spatoglossum variabile & Figari \& De Notaris & & + & + & & \\
\hline Stoechospermum marginatum & (C. Agardh) Kützing & & + & + & + & \\
\hline Colpomenia sinuosa & (Mertens ex Roth) Derbies \& Solier & + & & & & \\
\hline Myriogloi sciurus & (Harvey) Kuckuck & + & & & & + \\
\hline Jolyna laminarioides & Guimaraes in Guimaraes et al. & + & & & & + \\
\hline Cystoseira trinodis & (Forsskål) C. Agardh & & + & + & + & \\
\hline Cystoseira myrica & (Gmelin) C. Agardh & & + & + & + & \\
\hline Sargassum binderi & Sonder & & + & + & + & \\
\hline Sargassum asperifolium & Hering et Martens ex J. Agardh & & & + & & \\
\hline Sargassum boveanum & J. Agardh & & + & + & + & \\
\hline Sargassum duplicatum & J. Agardh & + & & & & \\
\hline Sargassum ilicifolium & (Turner) C. Agardh & & + & + & + & \\
\hline Sargassum latifolium & (Turner) C. Agardh & & + & + & + & \\
\hline Sargassum sp. 1 & & & & + & + & \\
\hline Sargassum sp. 2 & & & & + & & \\
\hline Sargassum sp. 3 & & & & + & & \\
\hline Sargassum sp. 4 & & & & + & & \\
\hline Sargassopsis zanardinii & (Schiffner) Nizamuddin et al. & + & & & & + \\
\hline
\end{tabular}

(Appendix continued on next page) 
Appendix (continued)

\begin{tabular}{|c|c|c|c|c|c|c|}
\hline Species & Authority & $\mathrm{Mk}$ & $\mathrm{AD}$ & $\mathrm{Sh}$ & $\mathrm{Hm}$ & Gs \\
\hline \multicolumn{7}{|l|}{ Rhodophyta } \\
\hline Porphyra vietnamensis & (Linnaeus) J. Agardh & + & & & & + \\
\hline Porphyra cf denticulata & Leuring & + & & & & + \\
\hline Palmaria palmata & (Linnaeus) Kuntze & & + & + & + & \\
\hline Palmaria sp. & & & + & + & + & \\
\hline Dermonema frappieri & (Montagne \& Millardet) Borgeser & + & & & & + \\
\hline Galaxaura marginata & (Ellis \& Solander) Lamouroux & & + & + & + & \\
\hline Galaxaura obtusata & (Ellis \& Solander) Lamouroux & & + & + & & \\
\hline Scinaia fascicularis & (Turner) Biuonia & & + & + & + & \\
\hline Scinaia hatei & Borgesen & & & + & & \\
\hline Scinaia indica & Borgesen & & + & + & + & \\
\hline Gelidiella acerosa & (Forsskål) Feldmann \& Hamel & & & + & + & \\
\hline Gelidium pusillum & (Stackhouse) Le Jolis & + & & & & \\
\hline Pterocladia nana & Okamura & & + & + & + & \\
\hline Pterocladia cf. capillacea & (S. G. Gmelin) Bornet & + & & & & \\
\hline Grateloupia filicina & (Lamouroux) C. Agardh & & + & + & + & \\
\hline Halymenia floresia & (Clemente y Rubio) & & + & + & + & \\
\hline Halymenia venusta & Borgesen & & + & + & + & \\
\hline Halymenia durvillaei & Bory de Saint-Vincent & & & + & & \\
\hline Amphiroa anceps & (Lamarck) DeCaisne & & + & + & + & \\
\hline Jania capillacea & Harvey & & + & & & \\
\hline Portieria hornemannii & (Lyngbye) P. C. Silva & & + & + & + & \\
\hline Gracilaria canaliculata & Sonder & + & & + & + & \\
\hline Gracilaria corticata & J. Agardh & & + & + & + & \\
\hline Gracilaria dentata & J. Agardh & & + & & & \\
\hline Gracilaria foliifera & (Forsskål) Borgesen & & + & + & + & \\
\hline Gracilaria folifera & (Forsskål) Borgesen & & & & & \\
\hline f. aeruginosa & (Turner) Borgesen & & + & + & + & \\
\hline Gracilaria cf. millardetii & (J. Agardh) Montagne & & & + & & \\
\hline Gracilaria textorii & (Suringar) DeToni & & + & + & & \\
\hline Gracilaria verrucosa & (Hudson) Papenfuss & & + & + & + & \\
\hline Gracilaria sp. 1 & & & + & & & \\
\hline Gracilaria sp. 2 & & & & + & & \\
\hline Gracilariopsis lemaneiformis & (Bory) Dawson & & + & + & & \\
\hline Polycavernosa debilis & (Forsskål) Freedericq \& Norris & & + & & & \\
\hline Meristotheca papulosa & (Montagne) J. Agardh & + & & + & + & \\
\hline Sarconema filiforme & (Sonder) & + & + & + & + & \\
\hline Sarconema scinaioides & Borgesen & & + & + & & \\
\hline Solieria dura & (Zanardini) Schmitz & & + & + & & \\
\hline Solieria robusta & (Greville) Kylin & & + & + & + & \\
\hline Agardhiella sp. & & & + & & & \\
\hline Hypnea musiformis & (Wulfen) Lamouroux & & + & + & + & \\
\hline Hypnea pannosa & J. Agardh & + & & & & \\
\hline Hypnea valentiaea & (Turner) Montagne & & + & + & + & \\
\hline Botryocladia leptopoda & (J. Agardh) Kylin & & + & + & + & \\
\hline Botryocladia leptopoda & (J. Agardh) Kylin & & & & & \\
\hline f. luxurians & Borgesen & & & + & & \\
\hline Coelarthrum muelleri & (Sonder) Borgesen & & & + & + & \\
\hline Coelarthrum opuntia & (J. Agardh) Borgesen & + & + & + & + & \\
\hline Rhodymenia cf dissecta & Borgesen & & + & + & + & \\
\hline Rhodymenia cf australis & Borgesen & & + & + & + & \\
\hline Lomentaria squarrosa & (Kützing) Le Jolis & + & & & & \\
\hline Champia globulifera & Borgesen & & + & + & & \\
\hline Champia parvula & (C. Agardh) Harvey & & + & + & + & \\
\hline Champia plumosa & Anand & & + & & & \\
\hline Champia somalensis & Hauck & & + & + & + & \\
\hline Gastroclonium iyengarii & Srinivasan & & + & & & \\
\hline Callithamnion cf cordatum & Borgesen & + & & & & \\
\hline Callithamnion sp. 1 & & + & & & & \\
\hline Centroceras clavulatum & (C. Agardh) Montagne & + & + & + & + & + \\
\hline Ceramium flaccidum & (Kützing) Ardissone & & & + & + & \\
\hline
\end{tabular}


Appendix (continued)

\begin{tabular}{|c|c|c|c|c|c|c|}
\hline Species & Authority & Mk & $\mathrm{AD}$ & Sh & $\mathrm{Hm}$ & Gs \\
\hline Ceramium strictum & Harvey & & + & & & \\
\hline Ceramium taylorii & Dawson & & & + & + & \\
\hline Ceramium transversale & Collin \& Harvey & & + & + & + & \\
\hline Ceramium of tenuissimum & (Roth) Areschong & & & + & & \\
\hline Ceramium sp. & & & & + & & \\
\hline Spyridia filamentosa & (Wulfen) Harvey & & + & & & \\
\hline Crouania sp. & & + & & & & \\
\hline Griffithsia cf globifera & Harvey ex Kützing & & & + & & \\
\hline Wrangelia sceptrifera & J. Agardh & & & + & & \\
\hline Wrangelia cf. bicuspidata & Borgesen & & & + & & \\
\hline Dasya elongata & Sonder & & + & + & + & \\
\hline Dasya baillouviana & (S. G. Gmelin) Montagne & & + & + & + & \\
\hline Heterosiphonia crispella & (C. Agardh) Wynne & + & & & & \\
\hline Acanthophora muscoides & (Linnaeus) Bory & & + & + & + & \\
\hline Acanthophora spicifera & (Vahl) Borgesen & & + & + & & \\
\hline Chondria dasyphylla & (Woodward) C. Agardh & & + & + & + & \\
\hline Chondria sedifolia & Harvey & & + & & & \\
\hline Herposiphonia cf. secunda & (C. Agardh) Falkenberg & + & & & & \\
\hline Laurencia cf. elata & (C. Agardh) Harvey & + & & & & \\
\hline Laurencia obtusa & (Hudson) Lamouroux & + & & & & + \\
\hline Laurencia papillosa & (C. Agardh) Greville & & + & + & + & \\
\hline Laurencia parvipapillata & Tseng & + & & & & \\
\hline Laurencia pinnatifida & (Hudson) Lamouroux & + & & & & + \\
\hline Laurencia cf. patentiramea & (Montagne) Kützing & + & & & & \\
\hline Laurencia sp. 1 & & + & & & & \\
\hline Laurencia sp. 2 & & + & & & & \\
\hline Melnothamnus somalensis & Bornet \& Falkenberg & + & & & & + \\
\hline Polysiphonia crassicolis & Borgesen & + & + & + & + & \\
\hline Polysiphonia variegata & (C. Agardh) Zanardini & & & & + & \\
\hline Polysiphonia sp. & & & & & + & \\
\hline
\end{tabular}

\section{LITERATURE CITED}

Asare, S. O., Harlin, M. (1983). Seasonal fluctuations in tissue nitrogen for five species of perennial macroalgae in Rhode Island Sound. J. Phycol. 19: 154-157

Banaimoon, S. (1986). A preliminary study of algae of the P.D.R. Yemen. Proc. natl Acad. Sci. India 56: 124-132

Banaimoon, S. (1988a). On the marine algae of the People's Democratic Republic of Yemen. Proc. natl Acad. Sci. India 58: $235-242$

Banaimoon, S. (1988b). The marine algal flora of Khalf and adjacent regions, Hadramout, P.D.R. Yemen. Botanica mar. 31. 215-221

Banaimoon, S. (in press). The intertidal marine algae of Sheher, Republic of Yemen - an area of upwelling in the Arabian Sea. Mar environ. Res.

Barratt, L., Ormond, R. F. G., Campbell, A. C., Hiscock, S., Hogarth, P. J., Taylor, J. D. (1984). An ecological study of the rocky shores on the south coast of Oman. Council for Conservation of the Environment and Water Resources, Muscat, p. 54

Barratt, L., Ormond, R. F. G., Wrathall, T. J. (1986). Ecological studies of southern Oman kelp communities. Council for Conservation of the Environment and Water Resources, Muscat, p. 99

Basson, P. W., Burchard, J. E., Hardy, J. T., Price, A. R. G. (1977). Biotopes of the western Arabian Gulf. Aramco, Dhahran
Bottero, J. S. (1969). An analysis of upwelling of the south east Arabian coast during the summer monsoon. M.Sc. thesis, Oregon State University

Bruce, J. G. (1974). Some details of upwelling off the Somali and Arabian coasts. J. mar. Res. 32: 419-423

Bryceson. I. (1982). Seasonality of oceanographic conditions and phytoplankton in Dar es Salem waters. Univ. Sci. J. (Dar Univ.) 8: 66-76

Carlson, L. (1991). Seasonal variation in growth, reproduction and nitrogen content of Fucus vesiculosus $\mathrm{L}$. in the $\varnothing_{\mathrm{re}}$ sund, southern Sweden. Botanica mar. 34: 447-453

Chapman, A. R. O., Craigie, J. S. (1977). Seasonal growth in Laminaria longicruris: relations with dissolved inorganic nutrients and internal reserves of nitrogen. Mar Biol. 40: $197-205$

Croley, F. C., Dawes, C. J. (1970). Ecology of the algae of a Florida Key. I. A preliminary checklist, zonation and seasonality. Bull. mar. Sci. 20: 165-185

Currie, R. I. (1964). A fertile sea. Geogr. Mag. 37: 198-211

Currie, R. I. (1992). Circulation and upwelling off the coast of south-east Arabia. Oceanol. Acta 15:43-60

Currie, R. I., Fisher, A. E., Hargreaves, P. M. (1973). Arabian Sea upwelling. In: Zeitschel, B., Gerlach, S. A. (eds.) The biology of the Indian Ocean. Springer-Verlag, New York, p. $37-52$

Davison, I. R., Andrews, M., Stewart, W. P. D. (1984). Regulation of growth in Laminaria digitata: use of in vivo nitrate reductase activities as an indicator of nitrogen limitation in 
field populations of Laminaria spp. Mar. Biol. 84: 207-217

Fujita, R. M., Wheeler, P. A., Edwards, R. 1. (1989). Assessment of macroalgal nitrogen limitation in a seasonal upwelling region. Mar. Ecol. Prog. Ser. 53: 293-303

Gagne, J. A., Mann, K. H., Chapman, A. R. O. (1982). Seasonal patterns of growth and storage in Laminaria longicruris in relation to different patterns of availability of nitrogen in the water. Mar. Biol. 69: 91-101

Gerard, V. A. (1982). Growth and utilisation of internal nitrogen reserves by the giant kelp, Macrocystis pyrifera, in a low nitrogen environment. Mar. Biol. 66: 27-35

Gessner, F., Hammer, L. (1967). Die littorale Algenvegetation an den Küsten von Ost-Venezuela. Int. Rev. ges. Hydrobiol. 52: 657-692

Hanisak, M. D. (1979). Nitrogen limitation of Codium fragile $\mathrm{sp}$. tomentosoides as determined by tissue analysis. Mar. Biol. 50: 333-337

Jones, D. A., Ghamrawy, M., Wahbeh, M. I. (1987). Littoral and shallow subtidal environments. In: Edwards, A., Head, S. A. (eds.) The Red Sea. Pergamon Press, Oxford, p. $169-193$

Kraft, G. (1970). The red algal genus Eucheuma in the Philippines. Masters thesis, University of Hawaii, Honolulu

Lapointe, B. E. (1987). Phosphorus- and nitrogen-limited photosynthesis and growth of Gracilania tikvahiae (Rhodophyceaej in the Florida Keys: an experimental field study. Mar. Biol. 93: 561-568

Lapointe, B. E. (1989). Macroalgal production and nutrient relations in oligotrophic areas of Florida Bay. Bull. mar. Sci. $44: 312-323$

Lapointe, B. E., Littler, M. M., Littler, D. S. (1992). Nutrient availability to marine macroalgae in siliciclastic versus carbonate-rich coastal waters. Estuaries 15: 75-82

Lapointe, B. E., Tenore, K. R. (1981). Experimental outdoor studies with Ulva fasciata Delile. I. Interaction of light and nitrogen on nutrient uptake, growth and biochemical composition. J. exp. mar. Biol. Ecol. 53: 135-152

Lapointe, B. E., Tenore, K. R., Dawes, C. J. (1984). Interactions between light and temperature on the physiological ecology of Gracilaria tikvahiae (Gigartinales, Rhodophyta). I. Growth, photosynthesis and respiration. Mar. Biol. 80: $161-170$

Lewis, J. B. (1964). The ecology of rocky shores. English Universities Press, London

McClanahan, T. R. (1988). Seasonality in East Africa's coastal waters. Mar. Ecol. Prog. Ser. 44: 191-199

Misra, J. N. (1960). The ecology, distribution and seasonal succession of the littoral algae on the west coast of India. In: Proceedings of Symposium on Algology, 1959. Indian Council of Agricultural Research. New Delhi, p. $187-203$

Mooriani. S A (1979) Seasonal changes in the marine algal flora of the Kenya coast. Int. Symp. Mar. Algae Indian Ocean Region. Bhavnagar

Moorjani, S. A. (1982). Rocky shore zonation in Kenya: horizontal and vertical distribution patterns in the marine flora. Proc. Symp. coast mar. envir. Red Sea, Gulf of Aden and tropical western Indian Ocean. ALECSO / UNESCO Khartoum

Murphy, J., Riley, J. P. (1962). A modified single solution method for the determination of soluble phosphate in natural waters. Analyt. Chem. 27:31-36

Nizamuddin, M., Hiscock, S., Barratt, L., Ormond, R. F. G (1993). The occurrence and morphology of Sargassopsis gen. nov. (Phyaeophyta, Fucales) in southern Oman. Botanica mar. 36: 109-121

Parsons, T R., Maita, Y., Lalli, C. M. (1984). A manual of chemical and biological methods for seawater analysis. Pergamon, Oxford

Ray, G. C. (1975). A preliminary classification of coastal and marine environments. IUCN occasional paper. International Union for Conservation of Nature and Natural Resources, Morges

Santelices, S. (1977). Water movement and seasonal algal growth in Hawaii. Mar. Biol. 43: 225-235

Savidge, G., Lennon, G. J., Matthews, A. D. (1986). Ecological studies of southern Oman kelp communities, Part 2, A shore based survey of oceanographic variables in Dhofar region of southern Oman. Council for Conservation of the Environment and Water Resources, Muscat

Savidge, G., Lennon, J., Matthews, A. J. (1990). A shorebased survey of upwelling along the coast of Dhofar region, southern Oman. Cont. Shelf Res. 10: 259-275

Smith, R. L. (1968). Upwelling. Oceanogr. mar. Biol. A. Rev. 6: $11-46$

Smith, R. L., Bottero, J. S. (1977). On upwelling in the Arabian Sea. In: Angel, M. V (ed.) A voyage of discovery. Pergamon Press, Oxford

Stephenson, T A., Stephenson, A. (1972). Life between tidemarks on rocky shores. Freeman, San Francisco

Stromgren, T. (1986). Annual variation in growth rate of perennial littoral algae from the west coast of Norway. Aquat. Bot. 23: 361-369

Svedelius, N. (1906). Über die Algenvegetation eines cey. lonischen Korallenriffes, mit besonderer Rücksicht auf ihre Periodizität. In: Sernander, R., Svedelius, N., Noren, R. O. (eds.) Botaniska studier, tillaegnade F. R. Kjellman. Almquist and Wiksells Boktrycherie, Uppsala, p. 184-220

Taylor, W. R., Bernatowicz, A. J. (1969). Distribution of marine algae about Bermuda. Bermuda biol. Stn Res. spec. Publ. 1. $1-42$

Topinka, J. A., Robbins, J. V. (1976). Effect of nitrate and ammonia enrichment on growth and nitrogen physiology in Fucus spiralis. Limnol. Oceanogr. 21: 659-664

Manuscript first received: December 15, 1992

Revised version accepted: November 22, 1993 